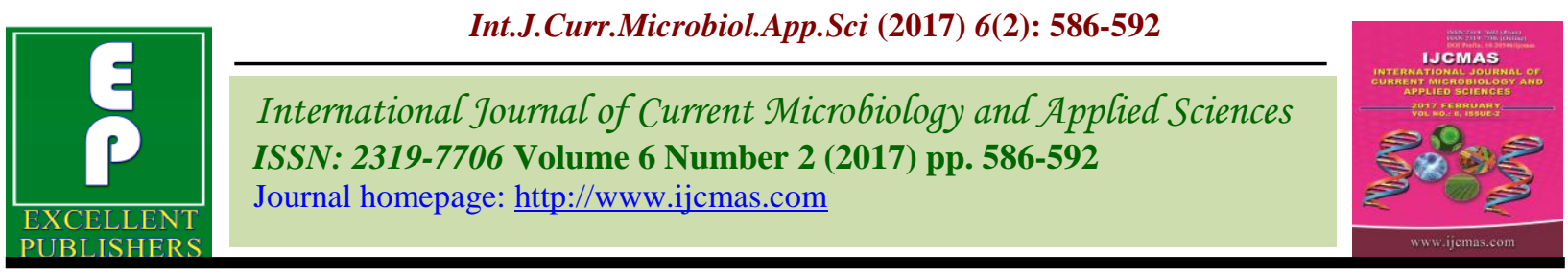

Original Research Article

http://dx.doi.org/10.20546/ijcmas.2017.602.066

\title{
Nutritional Quality of Hybrid Sorghum Genotypes
}

\author{
U.D. Chavan*, S.V. Nirmal, M.S. Shinde, G.H. Pawar, S.R. Gadakh and U.S. Dalvi \\ All India Co-ordinated Sorghum Improvement Project, Mahatma Phule Krishi \\ Vidyapeeth, Rahuri, India \\ *Corresponding author
}

\begin{tabular}{|c|c|}
\hline & A B T R A C T \\
\hline $\begin{array}{l}\text { Ke y w o r d s } \\
\text { Roti, Sorghum, } \\
\text { Bhakri, } \\
\text { Nutritional and } \\
\text { organoleptic } \\
\text { properties. }\end{array}$ & \multirow{3}{*}{$\begin{array}{l}\text { Sorghum grains are mostly used for the roti preparation. The M } 35-1 \text { (Maldhandi) a } \\
\text { sorghum cultivar is known for its good quality of roti due to having pearly white grain } \\
\text { colour, its flour having higher water holding capacity, and good organoleptic taste. } \\
\text { However, this cultivar is low yielder. To evolve sorghum high yielding hybrid genotype } \\
\text { coupled with good roti qualities, systematic breeding program was planned and executed } \\
\text { to overcome this problem. Fifteen newly developed genotypes of hybrid sorghum along } \\
\text { with check DSV } 6 \text { were studied for various nutritional quality parameters, with special } \\
\text { reference to the roti quality. Considering nutritional quality and organoleptic evaluation } \\
\text { parameters studied for roti quality, none of the newly developed hybrid genotype was } \\
\text { found superior than the check DSV } 6 \text {. However, CSH } 16 \text {, SHD } 36 \text {, CSH } 15 \text { and SHD } 6 \\
\text { were found to be promising for protein, sugar, water absorption, and soluble protein } \\
\text { content as well as for roti quality parameters. Therefore, they can be used for further } \\
\text { improvement in nutritional quality of hybrid sorghum genotypes through breeding } \\
\text { program. }\end{array}$} \\
\hline Article Info & \\
\hline $\begin{array}{l}\text { Accepted: } \\
\text { 15 January } 2017 \\
\text { Available Online: } \\
\text { 10 February } 2017\end{array}$ & \\
\hline
\end{tabular}

\section{Introduction}

Sorghum (Sorghum bicolor L. Moench) is the king of cereals and is one of the important food crops in dry lands of tropical Africa, India and China (Shobha et al., 2008). India ranks second in the world for sorghum production and first with respect to many regionally important crops like millets and pseudo-cereals. Sorghum is the principal staple food of Maharashtra, and is also an important food of Karnataka, Madhya Pradesh, Tamil Nadu and Andhra Pradesh (Anonymous, 2006a, b). Sorghum can be milled to produce starch or grits (semolina) from which many ethnic and traditional dishes can be made. The most common products are leavened and unleavened breads, porridges, boiled grains and steam cooked products such as couscous. Sorghum flour also makes an excellent fry coating for fish, chicken and beef. Sorghum is also used in the preparation of several snacks and for popping, chewing, and malting (Rao and Murty, 1981). There is a considerable variation in sorghum for levels of proteins, lysine, lipids, carbohydrates, fiber, calcium, phosphorus, iron, thiamine, and niacin (Chavan et al., 2009). Sorghum has chemical composition similar to or better than rice and wheat in some respects. The grains contain high fiber and non-starchy polysaccharides and starch with some unique characteristics. Protein quality and essential amino acid profile of sorghum is better than many of the cereals. 
Sorghum in general is rich source of Bcomplex vitamins.

Sorghum roti is very popular in villages and small towns as an accompaniment to gravy meat and vegetable curries and is one of the traditional recipes of India. It is round, flat, unleavened bread often used in the cuisine of western and central India, especially in the states of Gujarat, Sorghum roti is known by various names in the different languages of India: chapati (Hindi), bhakri (Marathi), rotla (Gujarati), rotte (Telugu), etc. (Subramanian and Jambunathan, 1981). Because sorghum flour is gluten-free flour, it is very tough to spread the dough without breaking the shape and one really needs hands-on experience and many failed attempts to get the skill. No leavening agents, oil/ghee are added. Just fresh sorghum flour, warm water and touch of fire - pure grain power in its glory. Arabinoxylans have been isolated from different cereals and responsible to play important role in maintaining water balance and rheological properties of dough (Michniewicz et al., 1991; Vietor et al., 1992; Nandini et al., 2001). Typically bhakri is accompanied by various curries, chutney (thecha - a thick paste of really hot green or red chilies) and raw onion (Murty and Subramanian, 1981; Subramanian and Jambhunathan, 1981, 1982). Bhakri has its own advantages from dietary point of view. Being made from cereals, it is high in dietary fiber but at the same time very easy to digest. Developing hybrid genotypes with high yield potential coupled with nutritionally superior quality grains is the prime objective of the breeding programme. This paper deals with the details of nutritional quality of hybrid grain sorghum genotypes developed through a systematic breeding programme and compared with the local check.

\section{Materials and Methods}

\section{Sorghum grains}

Hybrid sorghum grain samples were obtained from all India Co-ordinated Sorghum Improvement Project, Dharwad, Karnataka, India during Kharif-2015 season from advanced varietal and special trials.

\section{Cleaning sorghum grains}

The sorghum grains were cleaned to remove all extraneous material.

\section{Milling of sorghum grains}

Cleaned sorghum grains were subjected to milling in laboratory grinding mill. Whole sorghum flour was used for nutritional quality parameters testing and preparation of roti product.

\section{Nutritional quality of sorghum grain}

The sorghum grain flour was then analyzed for crude protein, total sugars, soluble protein, and free amino acids and phenolics contents using standard procedure of AOAC, (1990).

\section{Preparation of sorghum roti}

The flour was made from milling grains and fine flour was made in to dough with water. The $100 \mathrm{~g}$ sorghum flour was taken for preparation of roti. The dough was well kneaded, divided into small balls, flattened on a hard wooden or metal surface sprinkled with a small quantity of flour and was baked on both sides on a hot pan (Shobha et al., 2008). The prepared rotis were then kept in bamboo basket covered with cloth piece and stored at room temperature for studying the extension of shelf life.

\section{Sensory evaluation of sorghum roti}

The sensory evaluation for different quality parameters like colour and appearance, flavour, texture, taste and overall acceptability was carried out after every 4, 8, 12 and $24 \mathrm{~h}$ by semi trained panel of 10 judges on a 9 point hedonic scale (Amerine et al., 1980). 


\section{Statistical analysis}

All results obtained in the present study were analysed using standard methods of Panse and Sukatme, (1967).

\section{Results and Discussion}

Nutritional quality: Fifteen hybrids sorghum genotypes were studied for flour, dough, roti and nutritional quality and their results are presented in tables 1 and 2 .

Hectoliter weight: The hectoliter weight gives the soundness of the grain as well as higher recovery of the flour. It is a unit weight of the grain in a specific volume. The hectoliter weight of hybrid sorghum genotypes ranged from 71.75 to $77.91 \mathrm{~kg} / \mathrm{hl}$. The DSV 6 genotype gave higher hectoliter weight than rest of the hybrid genotypes studied.

Water absorption capacity: The water absorption capacity is positively correlated to the roti quality. The higher the water absorption capacity the superior was the quality of the roti. The water absorption capacity of flour ranged from 100 to $110 \%$. The hybrid genotype SPH 1737 gave higher water absorption percentage than other genotypes.

Crude protein: The crude protein content ranged from $7.82 \%$ (SPH 1724) to $10.70 \%$ (CSH 16) in the sorghum genotypes studied (Table 1). Similar results reported by Chavan et al., (2010) and Chavan and Patil (2010).

Soluble protein: The soluble protein content in the flour mostly responsible for the holding more water and developing smoothness to the roti. The soluble protein content in the hybrid sorghum flour ranged from $1.03 \%$ (SHD 6) to $1.35 \%$ (SPH 1737).
All hybrid sorghum genotypes were statistically significant different in their soluble content. Similar reports are available from Glover et al., (1986), Hulse et al., (1980) and Kolpfenstein and Hoseney (1995).

Total soluble sugars: The total soluble sugars in the hybrid sorghum genotype ranged from $1.17 \%$ (CSH 15) to $1.83 \%$ (SPH 1736). All the genotypes studied were significantly different. The higher sugar percentage in sorghum flour representing good amylolyptic activity while preparation of roti. Total soluble sugars are mostly responsible for good taste of the roti (Table 1). Similar results are reported by Chavan and Salunkhe (1984) and Chavan et al., (1989).

Starch: The starch content of the hybrid sorghum genotypes ranged from 52.04\% (CSH 23) to 58.61\% (CSH 30). Higher starch content gives good colour and amylopetic activity during roti preparation.

Free amino acids: The free amino acids in the hybrid sorghum genotypes ranged from $63.86 \mathrm{mg} / 100 \mathrm{~g}$ flour (CSH 30) to 81.19 $\mathrm{mg} / 100 \mathrm{~g}$ flour (DSV 6). The hybrid sorghum genotypes were statistically significantly different in the free amino acid content. This component mostly responsible for aroma development while roasting combines with moisture, soluble proteins and sugars.

Phenolics: The phenolics content in the studied genotypes ranged from $1.38 \%$ (CSH 30 ) to $2.92 \%$ (SHD 6).

The phenolics mostly responsible for astringent taste to the product but now-a-days it acts as antioxidants which prevent cancer development in human body (Salunkhe et al., 1984, Awika and Rooney, 2004). 
Table.1 Nutritional constituents responsible for roti quality prepared from different genotypes of Kharif hybrid sorghum

\begin{tabular}{|c|c|c|c|c|c|c|c|c|c|c|}
\hline Genotype & $\begin{array}{c}\text { Colour of } \\
\text { the grain }\end{array}$ & $\begin{array}{l}\text { Appearance/ } \\
\text { Shape of the } \\
\text { grain }\end{array}$ & $\begin{array}{l}\text { Hectoliter } \\
\text { weight } \\
(\mathrm{Kg} / \mathrm{hl})\end{array}$ & $\begin{array}{c}\text { Water } \\
\text { absorption } \\
(\mathrm{ml} / 100 \mathrm{~g})\end{array}$ & $\begin{array}{c}\text { Crude } \\
\text { Protein } \\
(\%)\end{array}$ & $\begin{array}{c}\text { Soluble } \\
\text { proteins (\%) }\end{array}$ & $\begin{array}{c}\text { Total } \\
\text { sugars } \\
(\%)\end{array}$ & Starch $(\%)$ & $\begin{array}{l}\text { Free amino } \\
\text { acids } \\
(\mathrm{mg} / 100 \mathrm{~g})\end{array}$ & $\begin{array}{c}\text { Phenolics } \\
(\%)\end{array}$ \\
\hline SPH 1736 & DB & RO & 72.39 & 100 & 9.67 & 1.26 & 1.83 & 54.87 & 73.40 & 1.40 \\
\hline SPH 1748 & DB & $\mathrm{RO}$ & 77.70 & 100 & 9.14 & 1.19 & 1.37 & 56.99 & 75.23 & 1.62 \\
\hline SPH 1724 & DB & RO & 76.17 & 100 & 7.82 & 1.22 & 1.18 & 53.25 & 72.26 & 1.40 \\
\hline CSH 30 & DB & RO & 76.53 & 105 & 8.58 & 1.06 & 1.27 & 54.28 & 70.16 & 1.38 \\
\hline SPH 1737 & DB & RO & 75.19 & 110 & 8.66 & 1.35 & 1.38 & 52.56 & 72.07 & 2.10 \\
\hline $\mathrm{CSH} 16$ & DB & RO & 76.11 & 100 & 9.32 & 1.34 & 1.40 & 52.50 & 74.02 & 1.95 \\
\hline CSH 25 & DB & RO & 75.15 & 100 & 9.80 & 1.06 & 1.46 & 52.20 & 74.63 & 2.00 \\
\hline CSH 23 & DB & $\mathrm{RO}$ & 74.62 & 100 & 9.36 & 1.31 & 1.26 & 52.04 & 71.71 & 2.44 \\
\hline CSH 14 & DB & RO & 73.39 & 110 & 9.25 & 1.12 & 1.25 & 54.47 & 66.30 & 2.41 \\
\hline CSH 15 & DB & RO & 71.75 & 110 & 9.10 & 1.17 & 1.17 & 56.67 & 70.21 & 2.57 \\
\hline CSH 16 & DB & RO & 73.59 & 100 & 10.70 & 1.27 & 1.67 & 57.27 & 75.94 & 2.51 \\
\hline CSH 30 & DB & RO & 74.35 & 100 & 8.75 & 1.19 & 1.17 & 58.61 & 63.86 & 2.10 \\
\hline SHD 6 & $\mathrm{DB}$ & $\mathrm{RO}$ & 72.90 & 100 & 10.48 & 1.03 & 1.57 & 55.26 & 75.97 & 2.92 \\
\hline SHD 36 & $\mathrm{DB}$ & RO & 73.41 & 100 & 10.36 & 1.07 & 1.58 & 57.16 & 69.84 & 2.64 \\
\hline DSV 6 & DW & $\mathrm{RO}$ & 77.91 & 100 & 9.70 & 1.14 & 1.52 & 53.73 & 81.19 & 1.52 \\
\hline Range & - & - & $71.75-77.91$ & $100-110$ & $\begin{array}{l}7.82- \\
10.70\end{array}$ & $1.03-1.35$ & $\begin{array}{l}1.17- \\
1.83\end{array}$ & $52.04-58.61$ & $63.86-81.19$ & $1.38-2.92$ \\
\hline Mean & - & - & 74.74 & 102 & 9.38 & 1.18 & 1.40 & 54.79 & 72.45 & 2.06 \\
\hline S.E. \pm & - & - & 1.81 & 4.02 & 0.74 & 0.10 & 0.19 & 2.05 & 4.05 & 0.49 \\
\hline C.D. at $5 \%$ & - & - & 5.44 & 12.10 & 2.25 & 0.31 & 0.58 & 6.16 & 12.15 & 1.48 \\
\hline
\end{tabular}

Replications: 3; Grain colour: Creamy $=\mathbf{C}$, Creamy White $=\mathbf{C W}$, Dull White $=\mathbf{D W}$, White $=\mathbf{W}$, Brown $=\mathbf{B}$, and Dull Black $=\mathbf{D B}$.

Grain Shape: Round $=\mathbf{R}$, Oval/Oblong $=\mathbf{O}$ and Wrinkle $=\mathbf{W}$. 
Table.2 Organoleptic quality of roti prepared from different genotypes of Kharif hybrid sorghum

\begin{tabular}{|c|c|c|c|c|c|c|c|c|c|c|c|c|}
\hline \multirow[t]{2}{*}{ Genotype } & \multirow{2}{*}{$\begin{array}{l}\text { Water } \\
\text { required } \\
\text { for } \\
\text { dough } \\
\text { (ml) }\end{array}$} & \multirow[t]{2}{*}{$\begin{array}{l}\text { Kneading } \\
\text { quality }\end{array}$} & \multirow[t]{2}{*}{$\begin{array}{c}\text { Spreading } \\
\text { quality }\end{array}$} & \multicolumn{5}{|c|}{ Organoleptic quality parameters } & \multirow{2}{*}{$\begin{array}{c}\text { Rank } \\
\text { by } \\
\text { DMRT }\end{array}$} & \multicolumn{3}{|c|}{$\begin{array}{c}\text { Loss in weight } \\
\text { during storage }(\%)\end{array}$} \\
\hline & & & & $\begin{array}{l}\text { Colour and } \\
\text { appearance }\end{array}$ & Flavour & Texture & Taste & $\begin{array}{c}\text { Overall } \\
\text { acceptability }\end{array}$ & & $4 \mathrm{hrs}$ & $8 \mathrm{hrs}$ & $\begin{array}{c}24 \\
\text { hrs }\end{array}$ \\
\hline SPH 1736 & 80 & 1 & 1 & 5.17 & 4.83 & 5.33 & 5.17 & 5.13 & 7 & 2.44 & 4.30 & 10.98 \\
\hline SPH 1748 & 90 & 1 & 1 & 5.00 & 5.83 & 5.50 & 6.33 & 5.67 & 5 & 2.70 & 4.73 & 11.08 \\
\hline SPH 1724 & 90 & 1 & 1 & 5.83 & 5.50 & 5.33 & 5.14 & 5.45 & 6 & 2.75 & 4.83 & 10.71 \\
\hline $\mathrm{CSH} 16$ & 90 & 1 & 1 & 5.17 & 5.33 & 4.83 & 4.67 & 5.00 & 8 & 2.48 & 4.74 & 11.91 \\
\hline CSH 25 & 90 & 1 & 1 & 5.17 & 4.67 & 5.33 & 4.83 & 5.00 & 8 & 2.45 & 4.63 & 11.55 \\
\hline CSH 23 & 90 & 1 & 1 & 4.17 & 4.83 & 4.50 & 4.17 & 4.42 & 9 & 2.56 & 4.67 & 10.89 \\
\hline CSH 14 & 90 & 1 & 1 & 4.83 & 4.17 & 4.50 & 4.17 & 4.42 & 9 & 2.45 & 4.42 & 10.86 \\
\hline $\mathrm{CSH} 15$ & 100 & 1 & 1 & 6.50 & 6.50 & 6.50 & 5.67 & 6.29 & 3 & 2.45 & 4.32 & 10.15 \\
\hline DSV 6 & 90 & 1 & 1 & 7.33 & 6.67 & 7.00 & 6.83 & 6.96 & 1 & 2.78 & 4.74 & 10.91 \\
\hline Range & $80-100$ & - & - & $4.17-7.33$ & $\begin{array}{c}4.17- \\
6.67\end{array}$ & $\begin{array}{c}4.50- \\
7.33\end{array}$ & $\begin{array}{c}4.17- \\
6.83\end{array}$ & $4.42-6.96$ & - & $\begin{array}{l}2.44- \\
3.15\end{array}$ & $\begin{array}{c}4.30- \\
4.83\end{array}$ & $\begin{array}{l}9.98- \\
11.91\end{array}$ \\
\hline Mean & 90 & - & - & 5.66 & 5.51 & 5.70 & 5.44 & 5.58 & - & 2.62 & 4.57 & 10.84 \\
\hline S.E. \pm & 4.83 & - & - & 0.95 & 0.74 & 0.96 & 0.92 & 0.85 & - & 0.18 & 0.18 & 0.48 \\
\hline $\begin{array}{l}\text { C.D. at } 5 \\
\%\end{array}$ & 14.49 & - & - & 2.87 & 2.22 & 2.89 & 2.79 & 2.57 & - & 0.55 & 0.57 & 1.44 \\
\hline
\end{tabular}

Kneading quality of dough, score: Good $=1$, Fair $=2$, Poor $=3$. Spreading quality of roti, score: Easy spreading without crack $=1$, Slightly difficult to spread with minute cracks $=\mathbf{2}$, Difficult to spread with cracks $=\mathbf{3}$.

Sensory score: $\quad$ Like extremely (Excellent) - 9, Like very much (Very good) - 8, Like moderately - 7, Like slightly-6, Neither like nor dislike - 5, Dislikes lightly - 4, Dislike moderately - 3, Dislike very much - 2, Dislike extremely-1. 


\section{Roti quality}

After sorghum grain yield, the organoleptic quality of sorghum roti is very important for consumer point of view. Therefore, hybrid genotypes of sorghum grown at Dharwad AICRP project during kharif-2015 season were used for the roti preparation and organoleptic evaluation (colour and appearance, texture, falvour/aroma, taste and overall acceptability using 1 to 9 hedonic scale rating). On the basis of these parameters and overall acceptability Duncan Multiple Range Taste was used to give the numbering for ranking the genotypes. For smoothness of the roti storage study was also conducted and water loss was measured at 4, 8 and $24 \mathrm{hrs}$.

Considering nutritional quality and organoleptic evaluation parameters studied for roti quality, none of the newly developed hybrid genotype was found superior than the check DSV 6. However, CSH 16, SHD 36, $\mathrm{CSH} 15$ and SHD 6 were found to be promising for protein, sugar, water absorption, and soluble protein content as well as for roti quality parameters (Table 2).

Similar results were reported by Bankar et al., (1986), Chavan et al., (1988, 2009, 2015).

\section{References}

Amerine, M.A., Pangborn, R.M. and Rossler, E.B. 1980. Principles of sensory evaluation of food. Academic Press, New York.

Anonymous. 2006a. Research Review Committee Meeting Report on Sorghum. Mahatma Phule Krishi Vidyapeeth Rahuri pp.1-182.

Anonymous. 2006b. Report on trials and nurseries kharif, rabi and forage sorghum. 36 ${ }^{\text {th }}$ Annual Group Meeting held at Marathwada Agricultural
University Parbhani. 11-13 May 2006. Vol. 2: pp. 209.

AOAC. 1990. Official Methods of Analysis. $15^{\text {th }}$ Edn. Association of Official Analytical Chemists, Washington, DC, pp.113-127.

Awika, J.M. and L.W. Rooney. 2004. Sorghum phytochemicals and their potential aspects on human health. Phytochem., 65: 1999-1221.

Bankar, J.R., Chavan, J.K. and Kadam, S.S. 1986. Effects of Incorporation of Sorghum Flour in wheat Maida on Physical and Sensory Properties of Bread, Buns, cookies and Biscuits. $J$. Maharashtra Agri. Univ., 11(2): 216218.

Chavan, U.D., Pansare, S.S., Patil, J.V. and Shinde, M.S. 2015. Preparation and Nutritional Quality of Sorghum Papads. Int. J. Curr. Microbiol. App. Sci., 4(5): 806-823.

Chavan, J.K., Salunkhe, D.K. 1984. Structure of sorghum grain in nutritional and processing quality of Sorghum. Qual. Plant. Pl. Foods Human Nutr., 29: pp.21-31

Chavan, J.K., Chavan, U.D. and Nagarkar, V.D. 1989. Effects of malting and fermentation on nutritional quality of sorghum. J. Maharashtra Agric. Univ., 14(2): 246-247.

Chavan, U.D., Patil, J.V. 2010. Grain Processing of Sorghum. Ibdc publishers, Lucknow. pp. 10-15

Chavan, U.D., Patil, J.V. and Shinde, M.S. 2009. Nutritional and roti quality of sorghum genotypes. Indonesian J. Agri. Sci., 10: 80-87.

Chavan, U.D., Bhagwat, V.R., Ratnavati, C.V., Patil, J.V., Gawali, H.S and Shailaja, V. 2010. Jwariche Ruchakar Padartha. Sorghum Research Centre, Rajendranagar, Hyderabad (India). Pp. 26.

Chavan, U.D., Chavan, J.K. and Kadam, S.S. 
1988. Effect of fermentation on soluble proteins and in-vitro protein digestibility of sorghum, green gram and sorghum + green gram blends. J. Food Sci., 53: 1574-1575.

Glover, J., Walker, C., and Mattern, P. 1986. Functionality of sorghum flour components in a high ratio cake. $J$. Food Sci., 51: 1280-1283, 1292.

Hulse, J.H., E.M. Laing and O.E. Pearson. 1980. Sorghum and Millets: Their composition and nutritive value. IDRC, Ottawa, Canada: Academic Press. Pp. 977.

Klopfenstein, C.F. and Hoseney, R.C. 1995. Nutritional properties of sorghum and millets. Dendy, D. A. V 125 St Paul, Minn.: American Association of Cereal Chemistry.

Michniewicz, J., Biliaderis, C.G. and Bushuk, W. 1991. Effect of added pentosans on some physical and technological characteristics of dough and gluten. Cereal Chem., 68: 252-258.

Murty, D.S. and Subramanian, V. 1981. Sorghum Roti: I. Traditional Methods of Consumption and Standard Procedures for Evaluation. Proceedings of the International Symposium on Sorghum Grain Quality, 73-78.

Nandini, C.D. and Salimath, P.V. 2001. Structural features of arabinoxylans from sorghum having good roti-making quality. Food Chem., 74: 417 - 422.
Panse, V.G. and Sukhatme, P.V. 1967. Statistical Methods for Agricultural Workers $2^{\text {nd }}$ Edn. I.C.A.R., New Delhi.

Rao Prasada, K.E. and Murty, D.S. 1981. Sorghum for Special Uses. Proceedings of the International Symposium on Sorghum Grain Quality, 129-134.

Salunkhe, D.K., J.K. Chavan and S.J. Jadhav. 1984. Nutritional and processing quality of sorghum. Oxford and IBH Publishing Co, New Delhi Pp. 275.

Shobha, V., Kasturiba, B., Naik, R. K. and Yenagi, N. 2008. Nutritive Value and Quality Characteristics of Sorghum Genotypes. Karnataka J. Agri. Sci., 20: 586-588.

Subramanian, V. and Jambhunathan, R. 1982. Properties of sorghum grain and their relationship to roti quality. In: International Symposium on sorghum grain quality. ICRISAT, Patancheru, India. pp. 280-288.

Subramanian, V. and Jambunathan, R. 1981. Properties of Sorghum Grain and their Relationship to Roti Quality. Proceedings of the International Symposium on Sorghum Grain Quality, 286-288.

Vietor, R.J., Angelino, S.A.G.F. and Voragen, A.G.J. 1992. Structural features of arabinoxylans from barley and malt cell wall material. J. Cereal Sci., 15: 213222.

\section{How to cite this article:}

Chavan, U.D., S.V. Nirmal, M.S. Shinde, G.H. Pawar, S.R. Gadakh and Dalvi, U.S. 2017. Nutritional Quality of Hybrid Sorghum Genotypes. Int.J.Curr.Microbiol.App.Sci. 6(2): 586592. doi: http://dx.doi.org/10.20546/ijcmas.2017.602.066 